\title{
RELEVANSI TATA KELOLA PUBLIK DAN ETIKA PERUSAHAAN
}

\begin{abstract}
This study aims to investigate the association of public governance and corporate ethics. Motive of the study was driven by numerous corporate scandals in various countries and practice of good governance both in private and public sector. The study was intended to reveal, whether the country that apply good practice of governance will also lead good practice of corporate ethics in that country. The study adopted exploratory research design which are public governance and corporate ethics proxied as two independent variables. Public governance was represented by attributes namely public accountability, control of corruption, effectiveness government, regulatory quality, rule of law, regulatory quality and political stability. The results show that all public governance attributes are positively and significantly associated with corporate ethics. Pearson correlation coefficient indicates that all attributes of public governance have strong correlation (Pearson correlation $(r)>0.6)$, except for public accountability attribute. The result implies that the practice of good governance in governmental sector have potential impact on how private sector running their business organizations.
\end{abstract}

ABSTRAK: Penelitian ini bertujuan untuk mengetahui hubungan antara tata kelola publik dan etika perusahaan. Motif penelitian ini didorong oleh berbagai skandal perusahaan di berbagai negara dan praktik tata kelola yang baik di sektor swasta dan publik. Studi ini dimaksudkan untuk mengungkapkan, apakah negara yang menerapkan praktik tata kelola yang baik juga akan mengarah pada praktik etika perusahaan yang baik di negara tersebut. Studi ini mengadopsi desain penelitian eksplorasi yang mana tata kelola publik dan etika perusahaan diproksi sebagai dua variabel independen. Studi ini menerapkan analisis korelasi bivariat dan melibatkan 140 negara anggota Bank Dunia. Hasil penelitian menunjukkan bahwa semua atribut tata kelola publik secara positif dan signifikan terkait dengan etika perusahaan. Koefisien korelasi Pearson menunjukkan bahwa semua atribut tata kelola publik memiliki korelasi kuat (korelasi Pearson (r) > 0,6), kecuali untuk atribut akuntabilitas publik. Hasilnya menyiratkan bahwa praktik tata kelola yang baik di sektor pemerintah memiliki dampak potensial pada bagaimana sektor swasta menjalankan organisasi bisnis mereka.

\author{
Sofik Handoyo ${ }^{1}$, \\ ${ }^{1}$ Fakultas Ekonomi \& Bisnis, \\ Universitas Padjajaran \\ Dipati Ukur 35, Bandung, \\ Indonesia
}

Keywords: Public Governance, Company Ethics,

Accountability, World

Governance Index, Global

Competitiveness Index

Kata Kunci: Tata Kelola Publik, Etika Perusahaan, Akuntabilitas, World Governance Index, Global Competitiveness Index 


\section{Pendahuluan}

Dalam dunia yang sangat kompetitif saat ini, perusahaan beroperasi di pasar global yang kompleks dan tata kelola perusahaan menjadi penting untuk mengatur hubungan ekonomi dan sosial (Arrigo, 2006). Masalah etika merupakan perhatian utama bagi bisnis karena mereka memiliki dampak signifikan pada berbagai pemangku kepentingan termasuk perusahaan, pelanggan, karyawan, pemegang saham, dan masyarakat pada umumnya (Ekici dan Onsel, 2013). Skandal perusahaan baru-baru ini telah menyebabkan tekanan publik untuk mereformasi praktik bisnis dan meningkatkan regulasi (Coglianese et al, 2004). Runtuhnya raksasa perusahaan seperti Enron dan Worldcom karena korupsi dan salah urus mengingatkan dunia akan pentingnya konsep seperti tata kelola perusahaan, tanggung jawab sosial dan etika bisnis (Tasyir dan Pasarcik, 2013). Skandal baru-baru ini sendiri menunjukkan bahwa lemahnya peraturan lembaga, standar, dan penegakan hukum dapat memiliki implikasi besar bagi ekonomi dan bagi publik (Coglianese et al, 2004).

Masyarakat menuntut akuntabilitas dan tanggung jawab dalam perilaku perusahaan. Tata kelola perusahaan telah menjadi hal utama dalam agenda kebijakan publik (Coglianese et al, 2004). Pemerintah memainkan peran penting dalam mendorong bisnis untuk berperilaku secara etis, baik dengan himbauan maupun paksaan, karena tidak dapat diasumsikan bahwa semua bisnis akan berperilaku etis tanpa penegakan peraturan (Breslin, 2017). Hurst (2004) menganggap bahwa isu tentang sustainability menimbulkan pertanyaan kritis tentang bagaimana etika perusahaan dapat mengatasi penyebab yang mendasari perilaku tidak bertanggung jawab perusahaan terhadap sosial dan lingkungan dalam mewujudkan praktik bisnis yang berkelanjutan. Dibutuhkan lebih dari sekadar kepemimpinan di internal sektor korporasi untuk memulihkan kepercayaan publik terhadap pasar modal Indonesia dalam memastikan isu sustainability dapat diwujudkan. Diperlukan peran pemerintah dalam bentuk pemerintah yang efektif, sistem peraturan yang direformasi, audit perusaahaan, dan penegakan hukum (Coglianese et al, 2004).

Meskipun pemerintah memainkan peran penting dalam memastikan bahwa bisnis beroperasi dalam koridor etika bisnis yang seharusnya, pada akhirnya, tanggung jawab untuk melakukannya terletak pada perusahaan. Tidak mungkin bagi pemerintah untuk mengawasi semua operasi sedemikian rupa sehingga mereka dapat memaksa semua perusaahaan untuk berperilaku etis. Pengawasan ketat seperti itu kemungkinan besar akan mempengaruhi kelancaran operasi pasar. Instansi pemerintah memegang tugas untuk mempromosikan etika perusaahan sebisa mungkin tanpa membatasi operasi bisnis (Breslin, 2017). Peran mendasar pemerintah dalam isu sustainability adalah sebagai lembaga pengatur, menetapkan standar, dan praktik penegakan hukum (Coglianese et al, 2004). Secara umum, perusahaan mematuhi pemerintah pada aspek yang dapat menimbulkan konsekuensi pidana pada jajaran direksi dan denda bagi perusahaan (Welsh, 2012)

Tata kelola publik mengacu pada pengaturan formal dan informal yang menentukan bagaimana keputusan publik dibuat dan bagaimana tindakan publik dilakukan, dari perspektif mempertahankan nilai-nilai konstitusional suatu negara ketika menghadapi masalah dan lingkungan yang berubah. Unsur-unsur utama tata kelola yang baik terdiri dari akuntabilitas, transparansi, efisiensi, efektivitas, daya tanggap, dan supremasi hukum (OECD, 2011). Tantangan terbesar saat ini adalah menyesuaikan tata kelola publik dengan perubahan sosial dalam ekonomi global (OECD, 2011). Ada hubungan yang jelas antara tata kelola publik yang baik, 
investasi dan pembangunan (OECD, 2011). Dengan demikian, institusi negara membutuhkan pendekatan yang fleksibel dalam desain dan implementasi pemerintahan publik yang efektif dan efesien (OECD, 2011).

Etika bisnis atau etika perusahaan terkait dengan norma-norma dan nilai-nilai moral (Tasyir dan Pasarcik, 2013). Faktorfaktor yang mempengaruhi perilaku etis dapat dikelompokkan ke dalam karakteristik individu pembuat keputusan, faktor organisasi, faktor situasional dan kontekstual, lingkungan sosial dan budaya, lingkungan bisnis / industri, dan lingkungan pemerintah dan hukum (Ekici dan Onsel, 2013). Yang melandasi dari tata kelola perusahaan yang baik adalah adalah etika (Sullivan, 2009). Namun demikian ada kecenderuangan praktik etika perusaahan antar negara terdapat variasi yang signifikan. Praktik etika perusahaan yang bervariasi antar negara dapat dijelaskan oleh perbedaan dalam lembaga politik, ekonomi, dan sosial (Sullivan, 2009).

Meskipun dampak potensial dari lingkungan politik dan hukum bisnis pada perilaku etis perusahaan telah diakui secara konseptual, tidak banyak bukti telah dihasilkan untuk memperjelas peran negara dalam etika perusaahan (Ekici dan Onsel, 2013). La Porta et al. (1999) mengeksplorasi faktor penentu kualitas pemerintahan. Mereka menemukan bahwa negara-negara kaya memiliki kecenderungan tata kelola pubik yang lebih baik daripada yang negara yang miskin dan bahwa ada bukti yang jelas bahwa keadaan historis (diukur dengan etnos linguistik, heterogenitas, asal-usul hukum dan agama) mempengaruhi kinerja pemerintah. Sistem tata kelola perusahaan berbeda secara signifikan antara berbagai negara (Lashgari, 2004). Oleh karena itu, memahami tata kelola publik lintas negara dan menganalisis hubungannya dengan praktik etika perusahaan di antara sektor swasta akan sangat berharga untuk menjawab peran pemerintah dalam memfasilitasi praktik bisnis yang baik.

Secara umum, penelitian ini menyelidiki hubungan praktik tata kelola publik dan praktik tata kelola perusahaan yang diwujudkan dari etika perusahaannya. Secara khusus, penelitian ini mencoba untuk mengungkapkan hubungan atribut tata kelola publik yaitu akuntabilitas publik, pengendalian korupsi, efektivitas pemerintah, kualitas peraturan, supremasi hukum, kualitas peraturan dan stabilitas politik dengan etika perusahaan. Studi ini melibatkan negara-negara yang terdaftar sebagai anggota bank dunia dan mengadopsi pendekatan penelitian eksplorasi. Analisis empiris menggunakan korelasi statistik diterapkan dalam penelitian ini untuk menganalisis hubungan atribut tata kelola publik dan etika perusahaan.

\section{Tinjauan Pustaka dan Pengembangan Hipotesis}

Akuntabilitas Publik dan Etika Perusahaan Akuntabilitas publik adalah ciri khas pemerintahan demokratis modern (Boven, 2003). Akuntabilitas publik mengukur kapasitas pemerintah terkait daya tanggap kepada masyarakat yang mencakup berbagai aspek proses politik, kebebasan sipil dan hak-hak politik, mengukur sejauh mana warga negara dapat mengambil bagian dalam pemilihan pemerintahan mereka (Bota-Avram, 2014). Akuntabilitas publik terkait dengan persepsi tentang sejauh mana warga negara suatu negara dapat berpartisipasi dalam memilih pemerintah mereka, serta kebebasan berekspresi, kebebasan berserikat, dan kebebasan media (Kaufmann et all, 2010). Akuntabilitas publik memungkinkan warga negara sebagai pemangku kepentingan menjadi bagian dari organisasi besar yang disebut sebagai negara. Setiap kegiatan yang dilakukan oleh negara atas nama warga negara itu harus dapat dipertanggungjawabkan kepada publik. 
Kemarahan publik atas skandal baru-baru ini telah memperjelas bahwa status quo tidak lagi dapat diterima, masyarakat menuntut akuntabilitas dan tanggung jawab dalam perusahaan. Etika perusahaan dapat membantu manajemen membuat perusahaannya lebih akuntabel dan transparan (Tasyir dan Pasarcik, 2013). Praktik demokrasi, akuntabilitas, dan transparansi di seluruh dunia telah mengurangi toleransi terhadap perilaku korup, dan meningkatkan standar tata kelola untuk perusahaan dan negara secara keseluruhan (Sullivan, 2009). Praktik akuntabilitas publik yang baik oleh pemerintah akan menciptakan lingkungan yang kondusif baik di sektor publik maupun sektoe swasta. Perusahaan swasta akan memiliki kecenderungan untuk mengadopsi apa yang sudah dipraktikkan pemerintah dalam hal penerapan tata kelola yang baik. Oleh karena itu, dari penjelasan tersebut diatas dapat dirumuskan hipotesis sebagai berikut:

Hipotesis 1: Semakin tinggi kinerja negara dari segi akuntabilitas publiknya maka akan semakin tinggi skor praktik etika perusahaan pada negara tersebut.

Kualitas Regulasi dan Etika Perusahaan

Diperlukan peraturan perundangundangan untuk memastikan bahwa perusahaan mematuhi kewajiban etisnya dan publik tidak mendapatkan dampak negatif akibat praktik bisnis yang tidak bertanggung jawab (Breslin, 2017). Untuk itu diperlukan peraturan perundangundangan yang berkualitas. Negara memerlukan peraturan dan perundagan yang berkualitas untuk menjamin kepentingan umum dapat dilindungi (Rhodes, 1997). Terkait dengan praktik bisnis, kualitas regulasi dirancang untuk menghindari dampak kebijakan yang dianggap tidak ramah pasar, seperti kontrol harga atau pengawasan bank yang tidak memadai, atau regulasi berlebihan yang dapat memengaruhi perkembangan bisnis
(Bota Avram, 2014). Kualitas regulasi mendorong masuknya investor asing dengan menghilangkan kebijakan pasar yang tidak ramah seperti kontrol harga, intervensi pemerintah, dan pembatasan pergerakan modal (Fazio dan Talamo, 2008).

Produk peraturan yang baik yang diterbitkan oleh negara untuk sektor bisnis dianggap penting untuk keberhasilan pembangunan ekonomi (Bota Avram, 2014, Kray dan Tawara, 2010). Praktik tata kelola perusahaan yang baik tidak dapat terwujud hanya dari dorongan faktor internal perusahaan saja. Fakor ekternal seperti halnya peraturan perundangundangan mempunyai kontribusi besar dalam praktik tata kelola perusahaan yang baik. Perusahaan akan merasa sulit untuk mematuhi peraturan tata kelola perusahaan jika tidak ada inisiatif untuk meningkatkan iklim hukum dan peraturan secara keseluruhan di suatu negara (Sullivan, 2009). Selain itu karakteristik hukumnya masing-masing negara, pemangku kepentingan juga berperan penting dalam tata kelola perusahaan (Vieira et all, 2010). Oleh karena itu, hipotesis dapat dirumuskan sebagai berikut:

Hipotesis 2: Semakin tinggi kinerja negara dari segi kualitas peraturan dan perundangannya maka akan semakin tinggi skor praktik etika perusahaan pada negara tersebut

Aturan Hukum dan Etika Perusahaan

Aturan hukum mencakup beberapa indikator yang memperkirakan sejauh mana masyarakat dan warga negara memiliki kepercayaan dan mematuhi aturan masyarakat, termasuk efektivitas sistem peradilan dan keamanan hak-hak properti (Bota-Avram, 2014). Aturan hukum juga mengukur sejauh mana masyarakat memiliki kepercayaan dan mematuhi aturan-aturan, termasuk efektivitas peradilan. Independensi peradilan adalah kekuatan pendorong di belakang persepsi 
manajer tentang etika bisnis (Ekici dan Onsel, 2013). Pada masalah desain aturan hukum, negara perlu memahami dengan baik krakteristik perusahaan dan konsekuensi hukum yang berlaku (Coglianese et al, 2004). Setiap sektor bisnis memiliki karakteristik berbeda yang mengarah pada perlakuan berbeda terhadap peraturan dan regulasi etika bisnis. Namun, kerangka kerja hukum dan peraturan dalam konteks nasional menetapkan standar minimum perilaku yang dapat diterima dalam melakukan bisnis, dan mencerminkan apa yang masyarakat anggap sebagai perilaku yang adil dan pantas oleh semua jenis dan ukuran perusahaan. Dengan demikian, kepatuhan terhadap hukum nasional adalah titik awal untuk melakukan hal yang benar oleh organisasi sektor swasta (Sullivan, 2009).

Etika bisnis, dalam beberapa hal, dapat dianggap sebagai sarana untuk memastikan bahwa individu yang bekerja dalam organisasi bertindak secara positif sesuai dengan aturan hukum dan prinsipprinsip lain yang menopang ekonomi pasar dan pemerintahan yang demokratis (Sullivan, 2009). Hukum dan peraturan negara tempat perusahaan beroperasi merupakan salah satu dari nilai-nilai yang dapat diturunkan dari etika bisnis (Sullivan, 2009). Dalam lingkungan aturan hukum yang lemah di mana sistem hukum untuk memastikan perilaku etis tidak dapat diandalkan, ada beberapa jaminan bahwa pelaku pasar lainnya akan berperilaku transparan dan adil (Sullivan, 2009). Oleh karena itu, hipotesis dapat dirumuskan sebagai berikut:

Hipotesis 3: Semakin tinggi kinerja negara dari segi aturan hukumnya maka akan semakin tinggi skor praktik etika perusahaan pada negara tersebut

Efektivitas Pemerintah dan Etika

Perusahaan

$\begin{array}{rrr}\text { Efektivitas } & \text { pemerintah terkait } \\ \text { dengan kinerja } & \text { pemerintah yang }\end{array}$

berhubungan dengan kualitas penyediaan layanan publik, kompetensi pegawai negeri sipil, tingkat birokrasi dan independensi layanan sipil (Bota Avram, 2014, Kaufmann, 2010). Negara berperan dalam menyelesaikan masalah-masalah sosial untuk memastikan lembaga sosial dan Lembaga ekonomi berfungsi dengan baik (Kooiman, 1999). Efektivitas pemerintah menyangkut kapasitas negara untuk menerapkan kebijakan yang sehat untuk stakeholders termasuk di dalamnya adalah organisasi bisnis (Rammal dan Zurbruegg, 2006). Efektivitas pemerintah memfasilitasi kegiatan investor asing melalui pengurangan birokrasi yang kompleks, prosedur, dan keseluruhan waktu yang diperlukan stakeholder untuk menyelesaikannya (Inter American Development Bank, 2001). Efektivitas pemerintah sangat fundamental terkait dengan pelayanan kepentingan umum dan kerja sama antara sektor publik dan sektor swasta (Bota Avram, 2014). Efektivitas pemerintah merupakan faktor pendorong bagi terwujudnya tata kelola perusahaan dan praktik bisnis yang baik termasuk didalam etika perusahaan.

Efektivitas pemerintah pada aspek penegakan hukum menjamin terselengaranya fungsi peraturan dan perundangan mengatur stakeholders pada koridor yang seharusnya. Praktik etika perusahaan yang tidak sesuai dengan norma sosial dan norma negara pada umumnya terjadi karena tidak efektifnya peran negara sebagai regulator. Pemerintah yang efektif salah satu indikatornya dapat dilihat dari kemampuan pemerintah untuk melaksanakan penegakan hukum yang optimal (Coglianese dkk, 2004). Kekhawatiran tentang perlindungan hak properti, etika dan korupsi, pengaruh yang tidak semestinya, dan inefisiensi pemerintah mengarah pada lingkungan kelembagaan yang tidak mendukung kegiatan ekonomi terlayani dengan baik (Ekici dan Onsel, 2013). Efektivitas 
pemerintah juga dapat diukur berdasarkan keberhasilannya mengatur tata kelola perusahaan yang baik secara proaktif di antara entitas bisnis. Ini akan tercermin pada perilaku etika bisnis yang dipraktikkan oleh sektor swasta. Oleh karena itu, hipotesis dapat dirumuskan sebagai berikut:

Hipotesis 4: Semakin tinggi kinerja negara dari segi efektivitas pemerintahannya maka akan semakin tinggi skor praktik etika perusahaan pada negara tersebut

Stabilitas Politik dan Etika Perusahaan

Stabilitas politik mengacu pada kondisi bahwa tidak adanya kemungkinan perubahan dalam struktur pemerintah yang berkuasa dapat digulingkan melalui perubahan yang inkonstitusional (Bota Avram, 2014).

Investor mempertimbangkan banyak faktor saat melakukan investasi di negara mana pun dan stabilitas politik adalah salah satunya. Setiap kali ada kondisi politik yang tidak stabil, industri akan terpengaruh (Aslam dan Sajid, 2008). Stabilitas politik mungkin tidak secara langsung memengaruhi praktik tata kelola dan etika perusahaan di sektor swasta. Namun, situasi politik yang kondusif memungkinkan entitas bisnis menerapkan prinsip-prinsip tata kelola perusahaan dengan tidak adanya gangguan dari faktor ekternal.

Hubungan erat antara kondisi ekonomi dan kondisi politik suatu negara merupakan salah satu hal yang paling menonjol di era industri (Coyle, 1999; Schwartz dan Gibb, 1999). Etika perusahaan secara global diatus dalam traktat yang diprakarsai oleh Deklarasi Universal Hak Asasi Manusia PBB (1948), Konvensi Eropa tentang Hak Asasi Manusia (1950), Helsinki Final Act (1975), OECD Pedoman untuk Perusahaan Multinasional (1976), Deklarasi Tripartit Kantor Perburuhan Internasional tentang Prinsip-prinsip Perusahaan Multinasional dan Kebijakan Sosial (1977), dan Kode Etik
PBB tentang Perusahaan Transnasional (1972). Dalam traktat tersebut menunjukkan bagaimana aspek politik suatu negara sangat erat dikaitkan dengan praktik bisnis sector swasta. Traktat secara umum mencakup lima bidang bisnis utama: praktik dan kebijakan karyawan, hak asasi manusia dan kebebasan mendasar, perlindungan konsumen, perlindungan lingkungan, dan keterlibatan politik (Ferrell dan Fraedrich, 1997). Oleh karena itu, hipotesis dapat dirumuskan sebagai berikut:

Hipotesis 5: Semakin tinggi stabilitas politik suatu negara maka akan semakin tinggi skor praktik etika perusahaan pada negara tersebut

Pengendalian Korupsi dan Etika Perusahaan

Pemerintah dan entitas bisnis adalah dua pihak yang saling menguntungkan satu sama lain. Peraturan dan regulasi pemerintah ditujukan untuk mengatur praktik bisnis sektor swasta. Namun, sektor swasta juga memiliki kontribusi bagaimana pemerintah harus mengembangkan peraturan dan regulasi. Sektor swasta dapat menjadi kekuatan dalam memberikan solusi untuk masalah korupsi birokrasi yang melibatkan pemerintah dan perusahaan. Kontribusi perusahaan dalam praktik pengendalian korupsi di pemerintahan dilakukan dengan beragam cara. Beberapa diantaranya adalah terlibat dalam aksi kolektif untuk mereformasi iklim bisnis agar lebih transparan. Aksi yang lain adalah mendorong standar etika dan praktik yang adil dalam berurusan dengan pemerintah, seperti halnya pakta integritas yang diprakarsai oleh industri (Sullivan, 2009). Faktor penting dalam menangani korupsi di pemerintahan adalah pendirian lembaga pengatur urusan publik dan swasta yang berintegritas (Sullivan, 2009)

Banyak peneliti menyimpulkan bahwa korupsi baik di sektor publik maupun di sector swasta tidak baik untuk praktik bisnis. Korupsi akan meningkatkan 
biaya transaksi dan pada akhirnya akan menurunkan daya saing. Hasil penelitian menunjukkan bahwa pembayaran tidak teratur dan suap adalah faktor yang paling berpengaruh yang mempengaruhi persepsi manajer tentang etika bisnis di ekonomi yang relatif lebih maju. Sedangkan perlindungan kekayaan intelektual adalah faktor paling berpengaruh yang mempengaruhi persepsi manajer tentang etika bisnis di negara yang kurang maju. (Ekici dan Onsel, 2013). Untuk mengendalikan korupsi dalam konteks sektor swasta, berbagai produk hukum dan peraturan diusulkan untuk ditegakan (Sullivan, 2009). Dalam situasi tersebut, peran pemerintah dalam hal memberantas praktik korupsi sangat penting. Oleh karena itu, hipotesis dapat dirumuskan sebagai berikut:

Hipotesis 6: Semakin tinggi kinerja pengendalian korupsi suatu negara maka akan semakin tinggi skor praktik etika perusahaan pada negara tersebut

\section{Metodologi Riset}

Populasi dan Sampel

Populasi dari penelitian ini adalah negaranegara yang terdaftar secara resmi sebagai anggota Bank Dunia. Hingga hari ini (2017), jumlah anggota di bank dunia adalah 214 negara (Populasi). Sementara itu, sampel digunakan dalam penelitian ini adalah 140 negara anggota bank dunia. Metode Purposive sampling diterapkan dalam penelitian ini. Hal ini mengacu pada tujuan ketersediaan data dalam periode waktu tertentu dari penelitian. Sampel mewakili lima benua yaitu Eropa, Amerika, Asia, Australia dan Afrika

Variabel, Pengukuran dan Data

Penelitian ini melibatkan dua variabel independen yaitu tata kelola publik dan etika perusahaan. Variabel-variabel tersebut diproksi sebagai dua variabel independen karena desain penelitian bersifat eksploratif. Atribut tata kelola publik diwakili oleh akuntabilitas publik, kualitas peraturan pemerintah, aturan hukum pemerintah, efektivitas pemerintah, stabilitas politik negara dan kontrol korupsi pemerintah. Atribut tata kelola publik diukur menggunakan Corporate Governance Index (CGI) yang dikeluarkan oleh Bank Dunia. CGI adalah kinerja tata kelola publik negara di seluruh dunia dan diadopsi secara global sebagai standar internasional untuk mengukur kinerja tata kelola publik. Sementara itu, etika perusahaan negara diukur menggunakan nilai etika perusahaan sebagai bagian dari Indeks Daya Saing Global (CGI) negaranegara. CGI diterbitkan oleh World Economic Forum sebagai indikator kinerja untuk mengukur daya saing negara. Data yang digunakan dalam penelitian ini adalah data sekunder, yaitu publikasi resmi Worldwide Governance Index (WGI) dan Global Competitiveness Index (GCI) dari Bank Dunia dan Forum Ekonomi Dunia. Data adalah publikasi terbuka dan diunduh langsung dari situs resmi sumber data. Periode waktu data yang digunakan dalam penelitian ini adalah tahun 2015, yang merupakan publikasi resmi terbaru yang tersedia dari sumber data.

Analisis Analisis

statistik deskriptif dan analisis korelasi bivariat diterapkan dalam penelitian ini. Analisis statistik deskriptif dimaksudkan untuk menggambarkan fitur dasar data yang digunakan dalam penelitian ini. Statistik deskriptif memberikan ringkasan sederhana tentang informasi dan data terkait sampel. Sementara itu, analisis korelasi bivariat dalam penelitian ini digunakan untuk menguji tingkat korelasi antara dua variabel independen. Selanjutnya, analisis korelasi bivariat digunakan untuk menganilisis penerimaan hipotesis yang diajukan. Metode Korelasi Pearson adalah dipilih dalam penelitian ini karena data dikategorikan sebagai skala interval.

\section{Hasil dan Diskusi \\ Statistik Deskriptif}


Bank Dunia Merilis Indikator Tata Kelola Dunia dalam nilai interval dari nilai minimum -2,5 (Kinerja tata kelola yang lemah) hingga $+2,5$ (Kinerja tata kelola yang kuat). Pengukuran tata kelola publik menggunakan enam indikator agregat berdasarkan 31 sumber data yang berdasarkan penilaian ahli di seluruh dunia. Seperti yang ditunjukkan pada Tabel 1, atribut tata kelola publik dari 140 negara sampel menunjukkan bahwa skor berada pada nilai sedang (nilai rata-rata 0,109). Deviasi standar juga menunjukkan bahwa negara-negara sampel memiliki karakteristik homogenitas dalam hal kinerja tata kelola publik. Didukung oleh statistik deskriptif bahwa nilai rata-rata deviasi standar yang menunjukkan jumlah yang relatif kecil (0,929945). Meskipun selalu ada outlier dengan kinerja ekstrem (lemah atau kuat), namun secara umum kita dapat menyimpulkan bahwa sampel dalam penelitian ini relatif memiliki karakteristik yang sama dalam hal kinerja tata kelola publiknya.

World Economic Forum mengembangkan indeks daya saing negara-negara menggunakan skala interval dari 1 (terburuk) sampai dengan 7 (yang terbaik). Salah satu indikator indeks daya saing negara adalah nilai etika perusahaan. Nilai etika perusahaan juga diukur dengan menggunakan nilai interval tujuh skala $(1=$ terburuk dan $7=$ terbaik). Tabel 2 menunjukkan bahwa nilai rata-rata etika perusahaan dari 140 negara sebagai sampel adalah 4,1123. Dengan pertimbangan 1 adalah yang terburuk dan 7 adalah yang terbaik, oleh karena itu, kita dapat menyimpulkan bahwa kinerja etika perusahaan negara yang digunalan dalam sampel penelitian ini berada pada level moderat. Informasi yang disajikan pada
Tabel 1. Statistik Deskriptif Tata Kelola Publik

\begin{tabular}{lcccc}
\hline $\begin{array}{l}\text { Varia } \\
\text { bel }\end{array}$ & Min & $\begin{array}{c}\text { Ma } \\
\mathbf{x}\end{array}$ & Mean & $\begin{array}{c}\text { Std. } \\
\text { Devias } \\
\text { i }\end{array}$ \\
\hline $\begin{array}{l}\text { Akunt } \\
\text { abilitas } \\
\text { Pemeri }\end{array}$ & $-1,76$ & 1,7 & 0,043 & 0,9132 \\
ntah & & & & 1 \\
$\begin{array}{l}\text { Stabilit } \\
\text { as }\end{array}$ & $-2,54$ & 1,49 & 0,041 & 0,8436 \\
$\begin{array}{l}\text { Politik } \\
\text { Efekti } \\
\text { vitas }\end{array}$ & $-2,00$ & 2,25 & 0,179 & 0,9477 \\
$\begin{array}{l}\text { Pemeri } \\
\text { ntahan }\end{array}$ & & & & 6 \\
$\begin{array}{l}\text { Kualit } \\
\text { as } \\
\text { regulas }\end{array}$ & $-1,86$ & 2,26 & 0,192 & 0,9255 \\
i & & & & 0 \\
\end{tabular}

\begin{tabular}{lcccc}
$\begin{array}{l}\text { Penge } \\
\text { ndalia } \\
\mathrm{n}\end{array}$ & $-1,33$ & 2,29 & 0,076 & 0,9880 \\
$\begin{array}{l}\text { Korup } \\
\text { si }\end{array}$ & & & & 2 \\
$\begin{array}{l}\text { Aturan } \\
\begin{array}{l}\text { Huku } \\
\text { m }\end{array}\end{array}$ & $-1,99$ & 2,07 & 0,123 & 0,9615 \\
\hline $\begin{array}{l}\text { Rata- } \\
\text { rata }\end{array}$ & & & & 7 \\
\hline
\end{tabular}

Tabel 2 menunjukkan bahwa nilai standar deviasi adalah pada mode level rendah (0.88333). Ini menunjukkan bahwa nilai variasi etika perusahaan di antara sampel relatif rendah. Deviasi standar yang rendah menjelaskan bahwa sampel relatif memiliki homogenitas dalam hal kinerja etika perusahaan dalm negara tersebut. Outlier data dari sample selalu ada, namun, sampel yang memiliki nilai ekstrem (terburuk atau terbaik) relatif kecil dalam hal jumlah. Nilai standar deviasi yang rendah juga menunjukkan bahwa sampel berada dalam mode distribusi normal. 
Tabel 2. Statistik Deskriptif Etika Perusahaan

\begin{tabular}{lcccc}
\hline Variabel & $\begin{array}{c}\text { M } \\
\text { in }\end{array}$ & $\begin{array}{c}\text { M } \\
\text { ax }\end{array}$ & $\begin{array}{c}\text { Me } \\
\text { an }\end{array}$ & $\begin{array}{c}\text { Std. } \\
\text { Deviasi }\end{array}$ \\
\hline Etika & 2. & 6.3 & 4.11 & 0.88333 \\
Perusahaan & 40 & 0 & 23 & \\
\hline
\end{tabular}

Analisis

Korelasi adalah cara lain untuk menilai hubungan antar variabel. Lebih tepatnya, untuk mengukur tingkat korespondensi antara dua variabel bebas. Korelasi menunjukkan saling ketergantungan antar variabel untuk mengkaitkan dua fenomena. Penelitian ini dikembangkan untuk mengidentifikasi hubungan antara dua variabel bebas. Karena tujuan penelitian ini adalah menginvestigasi hubungan antara dua variabel bebas, analisis statistik korelasi bivariat diyakini sebagai alat analisis yang tepat. Hasil analisis korelasi disajikan pada Tabel 3 .

Tabel 3. Matriks Korelasi

\begin{tabular}{lccccccc}
\hline Variabel & $\begin{array}{c}\text { Akuntabili } \\
\text { tas } \\
\text { Pemerinta } \\
\text { h }\end{array}$ & $\begin{array}{c}\text { Stabilit } \\
\text { as } \\
\text { Politik }\end{array}$ & $\begin{array}{c}\text { Efektivitas } \\
\text { Pemerinta } \\
\text { han }\end{array}$ & $\begin{array}{c}\text { Kualita } \\
\text { regulasi } \\
\text { rengendal } \\
\text { ian } \\
\text { Korupsi }\end{array}$ & $\begin{array}{c}\text { Atura } \\
\mathrm{n} \\
\text { Huku } \\
\mathrm{m}\end{array}$ & $\begin{array}{c}\text { Etika } \\
\text { Perusaha } \\
\text { an }\end{array}$ \\
\hline $\begin{array}{l}\text { Akuntabilitas } \\
\text { Pemerintah }\end{array}$ & 1 & & & & & \\
$\begin{array}{l}\text { Stabilitas } \\
\begin{array}{l}\text { Politik } \\
\text { Efektivitas }\end{array}\end{array}$ & 0,649 & 1 & & & & & \\
$\begin{array}{l}\text { Pemerintahan } \\
\text { Kualitas } \\
\text { regulasi }\end{array}$ & 0,710 & 0,730 & 1 & & & & \\
$\begin{array}{l}\text { Pengendalian } \\
\text { Korupsi }\end{array}$ & 0,732 & 0,762 & 0,921 & 0,884 & 1 & & \\
$\begin{array}{l}\text { Aturan } \\
\text { Hukum }\end{array}$ & 0,762 & 0,762 & 0,921 & 0,938 & 0,963 & 1 & \\
$\begin{array}{l}\text { Etika } \\
\text { Perusahaan }\end{array}$ & 0,481 & 0,601 & 0,921 & 0,760 & 0,872 & 0,834 & 1 \\
\hline
\end{tabular}

* semua nilai korelasi signifikan pada tingkat 0,01 (1-tailed).

Dalam penelitian ini, desain analisis korelasi adalah satu arah, yaitu merupakan korelasi positif. Argumen menggunakan uji analisis korelasi satu arah adalah karena literatur yang kuat mendukung arah hubungan antara dua variabel. Matriks Korelasi Pearson seperti yang disajikan pada Tabel 3 menunjukkan bahwa di antara atribut-atribut tata kelola publik (akuntabilitas publik, kualitas peraturan pemerintah, aturan hukum pemerintah, efektivitas pemerintah, stabilitas politik negara, dan kontrol korupsi pemerintah) memiliki korelasi kuat $(\mathrm{r}>0,6)$. Ini menyiratkan bahwa atribut tata kelola publik merupakan pengukuran indikator yang integral dan menunjukkan linearitas asosiasi. Integralitas dan linearitas berimplikasi bahwa kinerja satu atribut tata kelola publik akan dapat digunakan untuk memprediksi kinerja atribut lainnya dari negara tersebut. Jika satu atribut mendapat skor tinggi, itu juga akan menyebabkan 
skor tinggi pada atribut tata kelola publik yang lainnya.

Pengujian Hipotesis

Dalam penelitian ini, ada enam hipotesis yang diajukan dan ringkasan hipotesis disajikan pada Tabel 4. Secara umum, hipotesis memperkirakan bahwa tata kelola publik memiliki hubungan positif dan signifikan dengan etika perusahaan. Secara khusus, hipotesis mengajukan bahwa atribut tata kelola publik yaitu akuntabilitas publik, kualitas peraturan pemerintah, aturan hukum pemerintah, efektivitas pemerintah, stabilitas politik negara dan kontrol korupsi pemerintah secara positif dan signifikan terkait dengan etika perusahaan negara. Ringkasan pengujian hipotesis disajikan pada Tabel 4.

Berdasarkan informasi yang dirangkum dalam Tabel 4, disimpulkan bahwa semua hipotesis yang diajukan diterima. Semua atribut tata kelola publik menunjukkan korelasi positif dan signifikan dengan etika perusahaan. Namun, ada catatan untuk korelasi antara akuntabilitas publik dan etika perusahaan. Meskipun korelasinya positif dan signifikan, namun tingkat korelasinya moderat $(r=0,481)$. Ini berarti bahwa akuntabilitas publik sebagai atribut tata kelola publik tidak memiliki kekuatan yang meyakinkan untuk memprediksi kinerja etika perusahaan. Namun, secara umum kita masih dapat mengandalkan atribut tata kelola publik secara keseluruhan untuk memprediksi kinerja etika perusahaan. Argumen ini didukung oleh hasil statistik bahwa atribut tata kelola publik yang lain menunjukkan korelasi kuat dengan etika perusahaan $(r>0,6)$.
Tabel 4. Ringkasan Pengujian Hipotesis

\begin{tabular}{|c|c|c|}
\hline Hipothesis & $\begin{array}{c}\text { Pearson } \\
\text { Koefisien } \\
\text { Korelasi }\end{array}$ & Kesimpulan \\
\hline Akuntabilitas & $0,481 *$ & diterima \\
\hline publik $\rightarrow$ & & \\
\hline Etika & & \\
\hline Perusahaan & & \\
\hline Kualitas & $0,760 *$ & diterima \\
\hline Regulasi & & \\
\hline$\rightarrow \quad$ Etika & & \\
\hline Perusahaan & & \\
\hline $\begin{array}{l}\text { Aturan } \\
\text { Hukum }\end{array}$ & $0,834 *$ & diterima \\
\hline$\rightarrow \quad$ Etika & & \\
\hline Perusahaan & & \\
\hline Efektivitas & $0,801 *$ & diterima \\
\hline Pemerintah & & \\
\hline$\rightarrow \quad$ Etika & & \\
\hline Perusahaan & & \\
\hline $\begin{array}{l}\text { Stabilitas } \\
\text { Politik }\end{array}$ & $0,601 *$ & diterima \\
\hline$\rightarrow \quad$ Etika & & \\
\hline Perusahaan & & \\
\hline Pengendalian & $0,872 *$ & diterima \\
\hline Korupsi $\rightarrow$ & & \\
\hline Etika & & \\
\hline Perusahaan & & \\
\hline
\end{tabular}

*Korelasi signifikan pada tingkat 0,01 (1tailed).

Berdasarkan analisis korelasi seperti yang digambarkan pada Tabel 4 mengisyaratkan bahwa negara yang memiliki skor tinggi tata kelola publik akan mempunyai skor yang tinggi pula untuk skor etika perusahaan di negara tersebut. Ini berarti bahwa praktik tata kelola publik yang baik akan berdampak pada praktik tata kelola perusahaan yang baik di sektor swasta di negara tersebut. Upaya pemerintah dalam hal penerapan prinsipprinsip tata kelola publik yang baik memiliki kontribusi tentang bagaimana organisasi sektor swasta menjalankan bisnis mereka berdasarkan prinsip-prinsip tata kelola perusahaan yang baik. Oleh karena itu, pemerintah memiliki peran 
penting dalam menciptakan suasana yang baik yang memfasilitasi praktik bisnis yang baik di organisasi sektor swasta.

\section{Kesimpulan, Keterbatasan, dan Saran}

Penelitian ini menyimpulkan bahwa tata kelola publik yaitu akuntabilitas publik, kualitas peraturan pemerintah, aturan hukum pemerintah, efektivitas pemerintah, stabilitas politik negara dan kontrol korupsi pemerintah secara positif dan signifikan terkait dengan etika perusahaan negara. Secara umum, tingkat korelasi tata kelola publik dan etika perusahaan kuat, meskipun ada atribut tata kelola publik menunjukkan korelasi sedang. Mengacu pada hasil penelitian ini, tersirat bahwa kinerja tata kelola publik suatu negara mempunyai hubungan positif dengan kinerja etika perusahaan dinegara tersebut. Ini mendukung kerangka teori bahwa penerapan prinsip-prinsip pemerintahan yang baik di lembaga pemerintah akan mempengaruhi praktik tata kelola perusahaan yang baik di sektor swasta.

Pemerintah memainkan peran penting dalam hal mengkondisikan infrastruktur lingkungan bisnis yang menerapkan tata kelola yang baik. Upaya negara dalam mencapai tata kelola publik yang baik akan menarik praktik bisnis di sektor swasta ke arah yang sama. Sektor swasta akan mengikuti tindakan pemerintah dalam hal menerapkan praktik tata kelola yang baik. Meskipun linearitas antara tata kelola publik dan etika perusahaan terbukti, motif sektor swasta yang menerapkan praktik tata kelola yang baik masih dipertanyakan. Sektor swasta dapat mengikuti pemerintah menerapkan praktik tata kelola yang baik karena pertimbangan sendiri. Namun, praktik tata kelola publik yang baik juga memiliki kemungkinan untuk memaksa sektor swasta untuk menerapkan praktik tata kelola perusahaan yang baik (bukan dalam mode swasembada sektor swasta) Oleh karena itu, disarankan untuk melakukan penelitian lebih lanjut agar memahami lebih detail penerapan praktik yang baik etika perusahaan di antara organisasi sektor swasta.

Untuk mencapai praktik etika perusahaan yang baik, negara harus memiliki komitmen untuk memerangi praktik korupsi. Dengan memberantas perilaku korupsi di kalangan pejabat negara, kemungkinan praktik bisnis yang merusak dan membahayakan lingkungan bisnis dapat diminimalkan. Kualitas regulasi menentukan pencapaian tujuan regulasi itu sendiri. Dengan memiliki hukum dan peraturan yang benar-benar mempertimbangkan etika bisnis dan memiliki kekuatan untuk memaksa kepatuhan di antara para pemangku kepentingan, praktik etika perusahaan yang baik dapat dicapai. Stabilitas politik dalam negeri memungkinkan negara untuk melanjutkan program pembangunan nasional tanpa campur tangan apa pun. Negara akan memiliki perhatian untuk mengembangkan praktik bisnis yang baik terkait negara jika kondisi politik dalam negeri stabil. Efektivitas pemerintah memungkinkan pengembangan infrastruktur praktik bisnis yang baik di antara sektor swasta. Terakhir, akuntabilitas publik memaksa sektor swasta berperilaku positif dalam hal tanggung jawab terhadap pemangku kepentingan.

Untuk penelitian lebih lanjut, perpanjangan periode waktu investigasi sangat disarankan. Panel data longitudinal dengan lebih banyak negara yang terlibat direkomendasikan. Selanjutnya, analisis tingkat mikro tentang adopsi etika perusahaan adalah objek potensial dari penelitian mendatang yang dapat dilakukan. Dengan melakukan investigasi lebih rinci tentang penerapan praktik etika perusahaan yang baik di kalangan sektor swasta, diharapkan akan mendapatkan informasi yang lebih spesifik tentang peran tata kelola publik. Karena penelitian ini adalah studi eksploratif, yang mengangap hubungan antara variable adalah tidak 
saling mempengaruhi, dalam model analisis masa mendatang diharapkan menggunakan analisis regresi berganda. Menggunakan analisis regresi berganda, dampak akumulatif atribut tata kelola publik terhadap etika perusahaan akan dapat diestimasi. Oleh karena itu, analisis praktik tata kelola publik yang baik terhadap praktik tata kelola perusahaan yang baik adalah relevansi untuk diteliti dimasa mendatang 


\section{REFERENSI}

Arrigo, Elisa. (2006). Code of Conduct and Corporate Governance. Symphonya Emerging Issues in Management.

Aslam , M Shahzad., Ali Sajid., (2008). -Effect on Organizations and Quality due to Changed Employee Work Behaviors caused by Political Instability in Developing Countriesll. 1th QMOD Conference. Quality Management and Organizational Development Attaining Sustainability from Organizational Excellence to Sustainable Excellence; 20-22 August; 2008 in Helsingborg.

Bowen, Marks. (2003). Public Accountability. Paper for the EGPA annual conference, Oeiras Portugal September 3-6, 2003 to be presented in workshop 8 (Ethics and integrity of governance).

Breslin, Connor. (2017). -Role of Government in Business Ethics\|

(http://smallbusiness.chron.com/rolegovernment-business-ethics 65128. html, Accessed, 06 March, 2017).

Bota-Avram, Christina. (2014). Transylvanian Review of Administrative Science. Coglianese, Cary,Thomas J. Healey, Elizabeth K. Keating, and Michael L. Michael, -The

Role of Government in Corporate Governance, Regulatory Policy Program Report RPP-08 (2004), Cambridge, MA: Center for Business and Government, John F. Kennedy School of Government, Harvard University.

Coyle, D. (1999). The Weightless World: Strategies for Managing in the Digital Economy. Oxford: Capstone Publishing Ltd.

Ekici, Ahmet., Onsel, Sule. How Ethical Behavior of Firms is Influenced by the Legal and Political Environments: A Bayesian Causal Map Analysis Based on Stages of Development.

Fazio, G., Talamo, GMC (2008), - -How Attractive is Good Governance for FDI?\|, in J. Jay Choi, Sandra Dow (ed.) , -Institutional Approach to Global Corporate Governance: Business Systems and Beyondll, International Finance Review, Volume 9, Emerald Group Publishing Limited.

Ferrell, OC \& Fraedrich, J. (1997). Business Ethics. Boston: Houghton Mifflin. Hurst, NE (2004). Corporate Ethics, Governance ans Social Responsibility: Comparing European Business Practices to those in the United States, pp. 1-68.

Inter American Development Bank (2001), -Competitiveness: The Business of Growth: Economic and Social Progress in Latin Americall, 2001 Report, Research Department, Inter American Development Bank, Washington DC, USA.

Kaufmann, Daniel., Kraay, Aart., Mastruzz. (2010). - The Worldwide Governance Indicators: Methodology and Analytical Issues. Draft Policy Research Working Paper. World Bank.

Kooiman, J. (2003).Governing as Governance, London: Sage.

Kraay, A. and Tawara, N. (2010). Can Disaggregated Indicators Identify Governance Reform Priorities?', World Bank Policy Research Working Paper No. 5254, The World Bank Development Research Group.

La Porta, R., Lopez-de-Silanes, F., Shleifer, A., \& Vishny, R. (1999). The Quality of Government. Journal of Law, Economics, and Organization, pp. 222-279.

Lashgari, M. (2004). Corporate Governance: Theory and Practice. 
The Journal of American Academy of Business, pp. 46-51.

OECD, (2011). - Policy framework for investment user's toolkitl. A publication of the Investment Division of the OECD Directorate for Financial and Enterprise Affairs.

Rhodes, RAW, Understanding Governance. Policy Networks, Governance, Reflexivity and Accountability, Buckingham: Open University Press, 1997.

Rammal, H., \& Zurbruegg, R. (2006). The Impact of Regulatory Quality on Intra-Foreign Direct Investment Laws in the ASIAN Markets. International Business Review, 15 (4), 401-414.

Schwartz, P \& Gibb, B. (1999). When Good Companies Do Bad Things: Responsibility and Risk in an Age of Globalization. NY: John Wiley \& Sons.

Sullivan, John D. (2009). The Moral Compass of Companies: Business Ethics and Corporate Governance as Anti-Corruption Tools. International Finance Corporation. 2121 Pennsylvania Avenue, NW Washington.

Tasyir, Eyup Aygun., Pazarcik, Yener. (2013). Business ethics, social responsibility and corporate governance: Does the strategic management field really care about these concepts? Procedia - Social and Behavioral Sciences.

Valques, Manuel G. (2002). Business ethics: concepts and cases. (5rd ed.). Prentice Hall, USA.

Vieira, Inês Silva., Jorge, Maria João., Canadas, Natália Maria Rafael Prudêncio. (2010). Corporate Governance, Ethics and Social Responsibility: Comparing Continental European And AngloSaxon Firmsll. Proceeding
Conference on Environmental Management And Accounting.

Welsch, Ian. (2012). - How Important is Government Regulation of Business?l. http://hr.toolbox.com/blogs/searchfor-mutual-success/how-importantis-government- regulation-ofbusiness-50946 (Accessed, 06 March, 2017).

Riyanto, Bambang;. (2008). Dasar-Dasar Pembelanjaan Perusahaan. Yogyakarta:BPFE UGM.

Sansoethan, Dithya Kusuma; Suryono, Bambang;.(2016). FaktorFaktor yang Mempengaruhi Struktur Modal pada Perusahaan Makanan dan Minuman .Jurnal Ilmu dan Riset Akuntansi.

Santika, Rista Bagus; Sudiyatno, Bambang;. (2011). Menentukan Struktur Modal Perusahaan Manufaktur di Bursa Efek Indonesia. Dinamika Keuangan dan Perbankan, 3(2), 172-182.

Sartono, A;. (2012). Manajemen Keuangan Teori dan Aplikasi. Yogyakarta: BPFE.

Yoshendy, Andi; Achsani, Noer A; Maulana, TB N.A;. (2015). Analisis Faktor-Faktor yang Mempengaruhi Struktur Modal Perusahaan Barang Konsumsi di BEI 2002-2011. Jurnal Bisnis dan Manajemen, XVI, 47-59. 